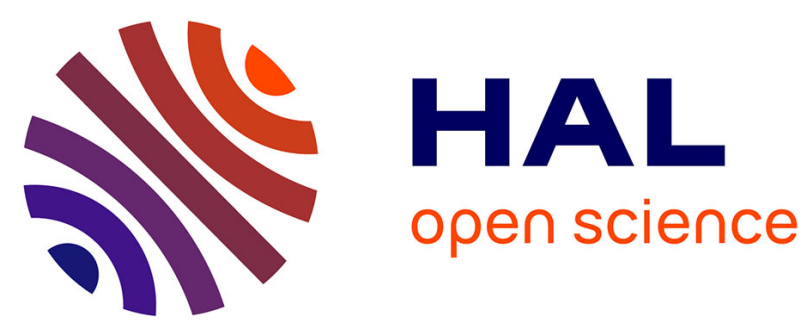

\title{
Energy Efficiency and Global Warming Potential of a Wind-Energy Complex at Brazilian Piauí State
}

\author{
Márcio Costa, Feni Agostinho, Cecília Almeida, Biagio F. Giannetti
}

\section{To cite this version:}

Márcio Costa, Feni Agostinho, Cecília Almeida, Biagio F. Giannetti. Energy Efficiency and Global Warming Potential of a Wind-Energy Complex at Brazilian Piauí State. IFIP International Conference on Advances in Production Management Systems (APMS), Sep 2016, Iguassu Falls, Brazil. pp.825834, 10.1007/978-3-319-51133-7_97. hal-01615721

\section{HAL Id: hal-01615721 \\ https://hal.inria.fr/hal-01615721}

Submitted on 12 Oct 2017

HAL is a multi-disciplinary open access archive for the deposit and dissemination of scientific research documents, whether they are published or not. The documents may come from teaching and research institutions in France or abroad, or from public or private research centers.
L'archive ouverte pluridisciplinaire HAL, est destinée au dépôt et à la diffusion de documents scientifiques de niveau recherche, publiés ou non, émanant des établissements d'enseignement et de recherche français ou étrangers, des laboratoires publics ou privés. 


\title{
Energy Efficiency and Global Warming Potential of a Wind-Energy Complex at Brazilian Piauí State
}

\author{
Márcio Costa, Feni Agostinho, Cecília M.V.B. Almeida and Biagio F. Giannetti \\ Paulista University (UNIP), São Paulo, Brazil \\ feni@unip.br
}

\begin{abstract}
The human addiction to fossil fuel and global warming leads to the search for alternative energy sources. The Brazilian government intends to increase its dependence on renewable energy sources, including hydropower, biomass, and wind. Many political and economic efforts have been directed to windenergy, however, there is a lack of case-specific information regarding its performance for $\mathrm{CO}_{2}$ emissions and dependence on fossil fuels. The aim of this work is to assess the global warming potential (GWP) and the fossil energy embodied in an important wind-energy complex located at Piauí State, Brazil. Results show that evaluated wind-complex demands lower amount of fossil energy $(0.0404$ $\mathrm{MJ})$ and has lower $\mathrm{GWP}\left(4.13 \mathrm{gCO}_{2-\text { eq. }}\right)$ per $\mathrm{kWh}$ of electricity generated when compared to landmark studies. Wind-electricity showed better performance than hydroelectricity $\left(0.1516 \mathrm{MJ} / \mathrm{kWh}\right.$ and $\left.11.84 \mathrm{gCO}_{2 \text {-eq. }} / \mathrm{kWh}\right)$, which supports wind-electricity as an important alternative towards an economy decarbonization.
\end{abstract}

Keywords: Embodied energy · Global warming · Wind-electricity.

\section{Introduction}

According to Wind Energy Brazilian Association (www.portalabeeolica.org.br), Brazil has the world's first position in the generation of clean and renewable electricity - i.e. it releases low amount of fossil carbon - mainly derived from hydro energy resources. Forty-five percent of Brazil's energy matrix comes from these so-called clean energy sources, which can be considered as a positive aspect when considering the global average of twenty percent. In addition, Brazil has several options to expand its clean and competitive electricity generation, including more hydropower, cogeneration, biomass, and wind energy.

The current worldwide concerns about climate change and the consequent efforts to reduce greenhouse gas emissions (GHG) led to the search for alternative systems of power generation that could reach high economic performance and, at the same time, generate less environmental impacts. Among others, an important political attitude comes as the growing economical investments in renewable energy sources such as wind energy. According to the Intergovernmental Panel on Climate Change [1], this energy source offers great potential for reducing GHG emissions. Although distributed unevenly among countries, wind-energy potential is greater than the current total world

adfa, p. 1, 2011.

(C) Springer-Verlag Berlin Heidelberg 2011 
electricity generation. Taking into account the political, economic and technological barriers, it is estimated that wind-energy could supply up to $20 \%$ of global electricity demand by 2050 [1]. In Brazil, the development of renewable energy sources is supported by the Incentive Program for Alternative Sources of Electric Energy (PROINFA), created by the Ministry of Mines and Energy (MME) by law no.10438/2002. The aim is to boost economies of scale, allow technological learning, increase the industrial competitiveness in domestic and foreign markets, and especially in assisting decision-making for future projects of electricity generation using cleaner and sustainable sources.

PROINFA aims to reach up to 2030 an amount of 3,300 MW installed capacity to be incorporated into the national integrated electricity system. Of this amount, 1,100 MW are planned to come from wind, 1,100 MW from small hydropower plants, and $1,100 \mathrm{MW}$ from biomass projects. From this strategic planning, it is expected an amount of avoided emissions of 2.5 million $\mathrm{tCO} 2 / \mathrm{yr}$, which could generate an environmental carbon emission certification under the Kyoto Protocol [2].

In addition to greenhouse gases, the reduction on fossil energy dependence also plays an important role in scientific and political discussions. The long term goals is to allow a societal development independent (or at least to a lesser extent) of fossil resources, which are considered non-renewable because their availability at low energy cost is being reduced over years [3]. According to the Brazilian Energy Plan for 2030 [2], the strategic planning is focused on energy efficiency increasing that could lead to a lower load on environment by demanding a reduced amount of resources, increase jobs opportunities, and increase market competitiveness. Energy efficiency addresses the energy consumption reduction, but also the opportunities for energy sources replacement towards a systemic efficiency gains.

In this scenario with reduced $\mathrm{CO} 2$ emissions and fossil energy dependence, wind energy has been considered as a potential alternative towards a cleaner Brazilian energy matrix. Although cleaner, wind energy necessarily generates environmental impacts. For example, although the wind farms do not use fossil energy sources to generate electricity and do not releases fossil carbon to atmosphere during functioning phase, they require a lot of energy resources and materials for construction, operation and maintenance phases that could cause even greater impact on the environment. Thus, before labeling an energy source as "clean", "green", "renewable" or other adjective related to sustainability, a quantitative diagnosis must be performed to support such label; careful attention must be driven to the entropic trap (term used by Ulgiati et al. [4]), i.e. the whole life cycle of the good or service must be considered in the evaluation. Thus, before claim that wind-electricity is a clean or green energy source, what is its global warming potential and fossil energy demand?

This work aims to calculate the global warming potential and the fossil embodied energy in generating electricity from wind-energy at "Chapada do Araripe" wind-energy complex located at Piauí state, Brazil.

\section{Method}

\subsection{Case Study Description and Data Source}


This work evaluates the wind-energy complex called "Chapada do Araripe", located at Piaui state, Brazil (Figure 1). It was chosen as case study due to its socio-economic importance in generating wind-energy at Piauí state, as well as due to availability and updated data. This region is identified as the most appropriated place to install wind farms in Piaui state, due to landscape (accessibility and availability) and wind conditions. Within this complex, seven wind farms are being implemented and will generate about $500 \mathrm{GWh} / \mathrm{yr}$ of wind electricity (Table 1).

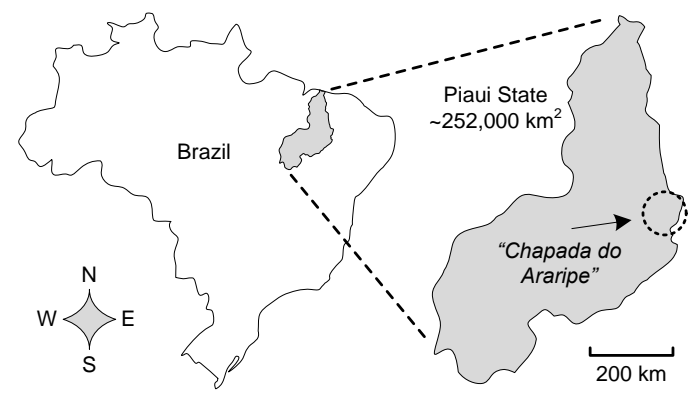

Fig. 1. Localization of "Chapada do Araripe" wind-energy complex in the Piaui State, Brazil.

Table 1. Main characteristics of the "Chapada do Araripe" wind-energy complex evaluated (195MW).

\begin{tabular}{lccc}
\hline Wind farms & $\begin{array}{c}\text { Land use } \\
\text { (ha) }\end{array}$ & $\begin{array}{c}\text { Wind-turbines a } \\
\text { (units) }\end{array}$ & $\begin{array}{c}\text { Electricity generated } \\
\text { (GWh/yr) }\end{array}$ \\
\hline Ventos de Santa Joana IX & 278 & 16 & 70.08 \\
Ventos de Santa Joana X & 353 & 16 & 70.08 \\
Ventos de Santa Joana XI & 187 & 16 & 70.08 \\
Ventos de Santa Joana XII & 593 & 17 & 74.46 \\
Ventos de Santa Joana XIII & 245 & 16 & 70.08 \\
Ventos de Santa Joana XV & 489 & 17 & 74.46 \\
Ventos de Santa Joana XVI & 443 & 17 & 74.46 \\
$\quad$ Total: & 2,588 & 115 & 503.70 \\
\hline
\end{tabular}

${ }^{\mathrm{a}}$ Model GE $1.7-100 \mathrm{MW}$ hh80m with $1.7 \mathrm{MW}$ of nominal power. ${ }^{\mathrm{b}}$ Average of generated electricity per each wind-turbine $=1 \mathrm{MWh} / \mathrm{h}$ or $8.76 \mathrm{GWh} / \mathrm{yr}$. Considering $50 \%$ for conversion efficiency, each turbine provides about $4.38 \mathrm{GWh} / \mathrm{yr}$ of electricity.

This work considers the processes of wind-turbines manufacturing, transportation, installation, operation and maintenance. Decommissioning was not included at this time due to lack of trustable available information. Regarding temporal analysis, it is considered 20-years of lifespan for wind-turbines (as considered by [5] and [6]), thus all resources needed in operating and maintaining the wind-turbines during this period are accounted for. Raw data on energy and materials comes mainly from Yang et al. [7], while raw data on labor and services were obtained in loco through direct interview with experts in the field. All raw data were carefully verified together with specialists who are currently in charge of several wind-farms projects being installed at Piauí state; including the wind energy complex assessed in this work. Detailed calculations on primary data are provided by Costa and Agostinho [8]. All energy intensity and $\mathrm{CO}_{2}$ equiv- 
alent factors were obtained from Ecoinvent Database v.3.1-2014 (the life cycle assessment database available at www.ecoinvent.ch) and available in Appendix A. Uncertainty analysis was not addressed in this work because single values of raw data for each system's input were considered, which implies that findings can be exclusively used to discuss about the analyzed system, and focusing on the previously established primary objectives of this study. For a future work it is intended to obtain raw data from other different wind-energy complexes and then run the Monte Carlo simulation for uncertainty analysis.

\subsection{Energy Efficiency and Global Warming Potential}

Sustainability is the goal for societal development - and maybe for its survival - by considering all potential problems related to overconsumption of energy and materials, as well as the increase amount of waste disposal. Based on a well-recognized sustainability indicator of ecological footprint, the Ecological Footprint Network (www.footprintnetwork.org) states that current society is living beyond the Earth's biocapacity. This claim for efforts towards a reduction of pressure that human is causing on nature. Among several indicators available on scientific literature that can subsidize decisions to achieve sustainability, the embodied energy demand and global warming potential are currently receiving special attention by society and worldwide scientific community. Due to this, and also because the evaluated system is an energy plant, the energy efficiency and global warming potential are considered as sustainability indicators in this work.

The load on environment affecting sustainability can, in general, be divided in "upstream" and "downstream"; deeper information regarding this approach can be found mainly in Ulgiati et al. [4]. "Upstream" load are related to all impacts caused far away from where the wind-farm is located, i.e. all emissions and fossil-energy demanded to make available all components existing in the wind turbines are considered. These loads are not caused by wind-farm locally, but they are caused in somewhere within the Earth and result in a load under a global perspective. For instance, Figure 2 shows that $\mathrm{CO}_{2}$ emissions are caused by the upstream process rather than the wind-farm itself. Differently, the "downstream" loads are those ones caused locally, during system installation, operation and maintenance. In this work, as the evaluated system is a wind-energy complex that converts wind energy into electricity, the local load on environment can be considered as insignificant compared to "upstream" loads and thus it was disregarded. The methodological approaches in calculating energy efficiency and global warming potential under the "upstream" approach are following described.

Embodied Energy Analysis [9]: This method aims to evaluate the direct and indirect gross energy requirement by the system. It offers a useful indicator about the energy efficiency of the produced good or service under a large scale view, i.e. it considers all "commercial" energy embodied. Commercial energy here is related to fossil energy. Energy intensity factors representing all fossil energy previously demanded to make available a good or service (usually in units of MJ/product) are used to convert all the systems input of matter and energy into fossil equivalent energy. In this work, the energy intensity factors provided by Ecoinvent Dataset v.3.1-2014 (www.ecoinvent.ch) 
are used. By adding the fossil energy equivalent of all system inputs will result in the gross energy required to generate wind-electricity, in units of $\mathrm{MJ} / \mathrm{kWh}$.

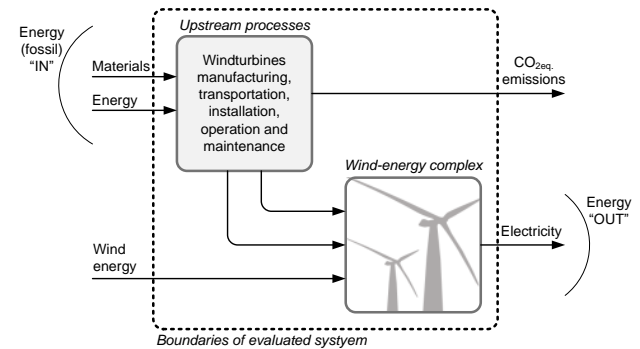

Fig. 2. Macro view of the evaluated system (dashed line) including two internal processes, the demand for materials and energy, and the outputs generated.

Global Warming Potential: Considering that evaluated wind-energy complex do not use fossil fuel or even burn any carbon-based energy resource locally to generate electricity, its emissions are located far away from where the wind-farms are installed. This "upstream" approach take into account all the indirect emissions released to make available all materials and energy used for components manufacturing, transportation, installation, operation and maintenance. For this, appropriated intensity factors provided by Ecoinvent Dataset v.3.1-2014 (www.ecoinvent.ch) that reflects the amount of $\mathrm{CO}_{2}$ equivalent released to atmosphere were used and are available in Appendix A; those intensity factors represents all emissions that can contribute to global warming potential. Additionally, all emissions due to diesel burned during transportation phase are also accounted by considering the emission factors provided by Sheehan et al. [10] as available in Appendix B. For this, the following $\mathrm{CO}_{2}$ equivalent factors published by Jensen et al. [11] are used: $\mathrm{CO}_{2}=1 ; \mathrm{CH}_{4}=62 ; \mathrm{N}_{2} \mathrm{O}=290 ; \mathrm{CO}=1.6 ;$ Hydrocarbons = 3.1. Both emission sources (indirect and direct, that occurred during transportation phase) when added provides the global warming potential in generating wind-electricity, in units of $\mathrm{kgCO}_{2 \mathrm{eq}} / \mathrm{kWh}$.

\section{Results and discussion}

Table 2 shows the results of embodied energy and $\mathrm{CO}_{2}$ emissions for the evaluated wind-energy complex as a whole, and to generate $1 \mathrm{kWh}$ of electricity as functional unit. Focusing on energy demand, fiber glass corresponds to $23 \%$ of total embodied energy, closer followed by steel $(20 \%)$ and concrete (19\%). While fiber glass and steel are mainly used during components manufacturing, concrete are used for wind-turbines installation. Copper and epoxy used during components manufacturing also reached a moderated importance on energy demand with 10 and $9 \%$ respectively. This indicates that aiming a reduction on fossil energy demand for the evaluated wind-energy complex, efforts should be directed to reduce the usage of fiber glass, steel and concrete mainly. The total energy embodied by the evaluated wind-energy complex is 2.04E7 $\mathrm{MJ} / \mathrm{yr}$ or $0.0404 \mathrm{MJ} / \mathrm{kWh}$. 
Table 2. Fossil fuel energy requirement and global warming potential (GWP) for the "Chapada do Araripe" wind-energy complex considering a 20 yrs lifespam.

\begin{tabular}{|c|c|c|c|c|c|c|}
\hline \multirow[b]{2}{*}{ Item } & \multirow[b]{2}{*}{ Amount $^{\mathrm{a}}$} & \multirow[b]{2}{*}{$\begin{array}{l}\text { Unit } \\
\text { /yr }\end{array}$} & \multicolumn{2}{|c|}{ Embodied energy } & \multicolumn{2}{|c|}{ GWP } \\
\hline & & & $\begin{array}{c}\mathrm{MJ} / \\
\mathrm{yr}\end{array}$ & $\begin{array}{l}\text { MJ } \\
(\%)\end{array}$ & $\begin{array}{c}\mathrm{kgCO}_{\text {2eq. }} \\
/ \mathrm{yr}\end{array}$ & $\begin{array}{r}\mathrm{kgCO}_{\text {2eq. }} \\
(\%)\end{array}$ \\
\hline \multicolumn{7}{|c|}{ Components manufacturing } \\
\hline Steel & $1.05 \mathrm{E}+03$ & ton & $4.25 \mathrm{E}+06$ & 20.88 & $3.61 \mathrm{E}+05$ & 17.32 \\
\hline Fiber glass & $1.29 \mathrm{E}+02$ & ton & $4.73 E+06$ & 23.24 & $4.03 \mathrm{E}+05$ & 19.36 \\
\hline Epoxy & $1.50 \mathrm{E}+01$ & ton & $1.83 \mathrm{E}+06$ & 9.01 & $1.25 \mathrm{E}+05$ & 6.00 \\
\hline Copper & $4.97 \mathrm{E}+01$ & ton & $2.21 \mathrm{E}+06$ & 10.87 & $2.29 \mathrm{E}+05$ & 11.01 \\
\hline Aluminum & $2.88 \mathrm{E}+00$ & ton & $2.54 \mathrm{E}+04$ & 0.12 & $2.42 \mathrm{E}+03$ & 0.12 \\
\hline Glass & $2.01 \mathrm{E}+00$ & ton & $2.43 \mathrm{E}+04$ & 0.12 & $2.22 \mathrm{E}+03$ & 0.11 \\
\hline Polyester & $1.73 \mathrm{E}+00$ & ton & $1.63 \mathrm{E}+05$ & 0.80 & $1.24 \mathrm{E}+04$ & 0.60 \\
\hline Labor \& services & $1.22 \mathrm{E}+07$ & USD & - & - & - & - \\
\hline \multicolumn{7}{|c|}{ Components transportation } \\
\hline Diesel (production) ${ }^{b}$ & $4.37 \mathrm{E}+11$ & $\mathrm{~J}$ & $6.25 \mathrm{E}+05$ & 3.07 & $4.29 \mathrm{E}+04$ & 2.06 \\
\hline Diesel (usage) ${ }^{b}$ & $4.37 \mathrm{E}+11$ & $\mathrm{~J}$ & - & - & $4.52 \mathrm{E}+04$ & 2.17 \\
\hline Steel & $3.67 \mathrm{E}-02$ & ton & $1.49 \mathrm{E}+02$ & $<0.00$ & $1.26 \mathrm{E}+01$ & $<0.00$ \\
\hline Labor \& services & $1.24 \mathrm{E}+06$ & USD & - & - & - & - \\
\hline \multicolumn{7}{|c|}{ Wind-turbine installation, operation \& maintenance } \\
\hline Wind & $7.55 \mathrm{E}+15$ & $\mathrm{~J}$ & - & - & - & - \\
\hline Concrete & $5.98 \mathrm{E}+03$ & ton & $3.87 \mathrm{E}+06$ & 19.01 & $6.29 \mathrm{E}+05$ & 30.21 \\
\hline Steel & $2.19 \mathrm{E}+02$ & ton & $8.86 \mathrm{E}+05$ & 4.35 & $7.52 \mathrm{E}+04$ & 3.61 \\
\hline Diesel (production) ${ }^{b}$ & $3.32 \mathrm{E}+11$ & $\mathrm{~J}$ & $4.75 \mathrm{E}+05$ & 2.33 & $3.26 \mathrm{E}+04$ & 1.56 \\
\hline Diesel (usage) ${ }^{\mathrm{b}}$ & $3.32 \mathrm{E}+11$ & $\mathrm{~J}$ & - & - & $3.44 \mathrm{E}+04$ & 1.65 \\
\hline Water & $1.74 \mathrm{E}+03$ & ton & - & - & - & - \\
\hline Electricity & $1.04 \mathrm{E}+12$ & $\mathrm{~J}$ & $1.67 \mathrm{E}+04$ & 0.08 & $7.32 \mathrm{E}+04$ & 3.52 \\
\hline Gasoline & $1.01 \mathrm{E}+12$ & $\mathrm{~J}$ & $1.24 \mathrm{E}+06$ & 6.10 & $1.45 \mathrm{E}+04$ & 0.70 \\
\hline Labor \& services & $1.24 \mathrm{E}+05$ & USD & & - & - & - \\
\hline Output electricity & $5.03 \mathrm{E}+08$ & $\mathrm{kWh}$ & & & & \\
\hline Total & & & $2.04 \mathrm{E}+07$ & & $2.08 \mathrm{E}+06$ & \\
\hline
\end{tabular}

${ }^{a}$ Most of raw data were obtained from Yang et al. [7], then complemented and verified by Brazilian experts which work on the wind-energy complex evaluated. ${ }^{b}$ Diesel (production) represents the energy demand and emissions related to diesel production, while diesel (usage) represents the emissions due to diesel burning during transportation phase. Emissions from diesel burning were estimated based on the emission factors available at Appendix $\mathrm{B}$ and the $\mathrm{CO}_{2}$ equivalent factors of section 2.2.

Focusing on $\mathrm{CO}_{2}$ emissions, a different figure was obtained. Concrete is the first emitter reaching $30 \%$ of total $\mathrm{CO}_{2}$ released to atmosphere by the evaluated wind-energy complex, followed by fiber glass (19\%), steel (17\%) and copper $(11 \%)$. Thus, in a scenario in which $\mathrm{CO}_{2}$ emission deserves higher attention than fossil energy demand, efforts should be done in reducing these materials. The total global warming potential for the evaluated wind-energy complex is $2.08 \mathrm{E} 6 \mathrm{kgCO}_{2 \text {-eq. }} / \mathrm{yr}$ or $4.13 \mathrm{gCO}_{2 \text {-eq. }} / \mathrm{kWh}$. Interesting to note that, although more than $2,500 \mathrm{~km}$ of covered distance by components transportation (e.g. rotor and tower are produced in the southeast region of Brazil) which demands high amount of diesel and steel for trucks, this phase can be considered as insignificant compared to components manufacturing and installation phases. 
Figure 3 shows the results obtained in this work compared to others obtained from scientific literature. For both indicators, embodied energy and global warming potential, the values obtained in this work are lower than referenced values, i.e. they represent better performance. The highest value obtained from literature for energy demand was $0.4680 \mathrm{MJ} / \mathrm{kWh}$ [12], a value about 11 times higher than obtained in this work $(0.0404$ $\mathrm{MJ} / \mathrm{kWh}$ ). Similar behavior can be seen by the GWP, in which the highest value found in literature (41.2 $\mathrm{gCO}_{2 \text {-eq. }} / \mathrm{kWh}$; Ecoinvent Database) correspond to about 10 times higher the GWP of $4.13 \mathrm{gCO}_{2 \text {-eq. }} / \mathrm{kWh}$ obtained in this work. These comparisons are an attempt to visualize, under a macroscopic view, an order of hierarchy among the assessed wind-energy systems. However, it must be emphasized that for a deeper comparison some changes should be done to standardize the coefficient factors used and scale considered for all referenced values. For instance, most works analyzed by Lenzen and Munksgaard [13] and Ecoinvent Database have considered the equipment's decommissioning phase while the present work disregarded this phase. Anyhow, the numbers obtained in this work could be considered as promising because they show better performance than those obtained by Yang and Chen [5] and Riposo [14] who have evaluated similar systems to this present work.

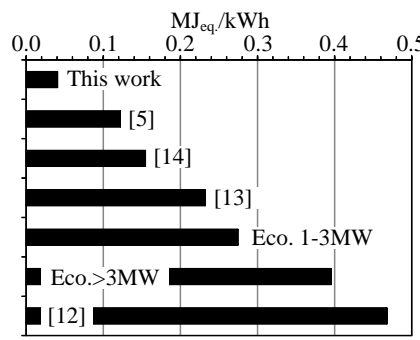

(a)

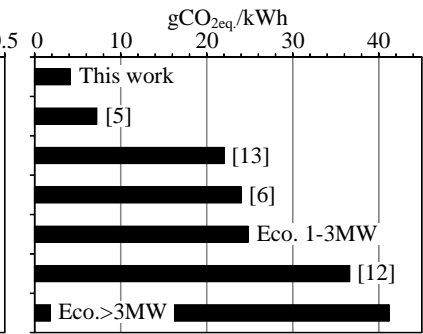

(b)

Fig. 3. Comparison of fossil embodied energy (a) and global warming potential (b) for different wind-electricity generation systems. Observations: for reference [13] a median value from 69 (embodied energy) and 29 (global warming) case studies was used; 1-3MW and $>3 \mathrm{MW}$ indicates the installed power of systems - data Ecoinvent Database.

After calculating the GWP and embodied energy for each kWh of electricity generated by the wind-energy complex evaluated, it is important a comparison of these indicators against the largest energy source for electricity produced and used in Brazil: hydropower (reaching 71\% of total). According to Brown and Ulgiati [12], hydropower releases $11.84 \mathrm{gCO}_{2 \text {-eq. }}$ per $\mathrm{kWh}$ of generated electricity, a value about three times higher than for wind-electricity obtained in this work $\left(4.13 \mathrm{gCO}_{2 \text {-eq. }} / \mathrm{kWh}\right)$. Regarding the embodied energy, the same authors provides a value of $0.1516 \mathrm{MJ} / \mathrm{kWh}$, which corresponds to about 3.7 times higher than the $0.0404 \mathrm{MJ} / \mathrm{kWh}$ obtained in this work. In short, both indicators show better performance for the wind-electricity than hydroelectricity.

It is recognized that a political decision on such important issue for the Brazilian society (energy) should consider several other indicators than exclusively GWP and energy demand. For instance, differently from hydropower, wind is a seasonal energy source that varies along year, it is impossible to storage this energy source for better management, the proper functioning of wind turbines depends on weather conditions, 
storms can damage wind turbines and electricity generation can become interrupted, economical aspects, social aspects, etc. Anyhow, this work presents that, considering the evaluated wind energy complex, generating electricity from wind energy results in lower global warming potential, (i.e. it releases lower amount of fossil carbon to atmosphere) and it demands lower amount of fossil energy than hydroelectricity.

\section{Conclusions}

The embodied energy and global warming potential for the "Chapada do Araripe" wind-energy complex evaluated are 2.04E7 $\mathrm{MJ} / \mathrm{yr}$ and $2.08 \mathrm{E} 6 \mathrm{kgCO}_{2 \text {-eq. }} / \mathrm{yr}$ respectively. Considering the functional unit of electricity generated, values obtained were $0.0404 \mathrm{MJ} / \mathrm{kWh}$ and $4.13 \mathrm{gCO}_{2 \text {-eq. }} / \mathrm{kWh}$. Both numbers are lower (i.e. higher performance) than other found in scientific literature, which implies that generating electricity from wind-energy by the evaluated system demands lower amount of fossil energy and releases lower amount of greenhouse gases to atmosphere compared to referenced systems.

Comparing hydroelectricity - the highest energy source for electricity generation in Brazil, 71\% - against wind-electricity, indicators show that generating electricity from hydropower demands higher amount of fossil fuel $(0.1516 \mathrm{MJ} / \mathrm{kWh})$ and releases higher amount greenhouse gases to atmosphere $\left(11.84 \mathrm{gCO}_{2 \text {-eq. }} / \mathrm{kWh}\right)$, indicating that wind-energy is an important alternative towards an economy decarbonization as envisioned by the Brazilian government for the next 30 years.

Acknowledgements. This work received financial support from the Vice-Reitoria de Pós-Graduação e Pesquisa of Universidade Paulista (UNIP). Thanks also to CNPq Brazil (proc. no. 307422/2015-1) for the fellowship provided to second author.

\section{References}

1. Intergovernmental Panel on Climate Changes, http://www.ipcc.ch.pt.mk.gd/activities/activitie s.shtml

2. Brazilian Energy Plan, http://www.mme.gov.br/web/guest/publicacoes-e-indicadores/matriz-energetica-nacional-2030

3. Odum, H.T., Odum, E.: A Prosperous Way Down: Principles and Policies. Boulder, University Press of Colorado (2001)

4. Ulgiati, S., Raugei, M., Bargigli, S.: Overcoming the Inadequacy Of Single-Criterion Approaches to Life Cycle Assessment. Eco. Mod. 190, 432-442 (2006)

5. Yang, J., Chen, B.: Integrated Evaluation of Embodied Energy, Greenhouse Gas Emission and Economic Performance of a Typical Wind Farm in China. Ren. Sus. Ener. Rev. 27, 559$568(2013)$

6. Dolan, S.: Life cycle assessment and emergy synthesis of a theoretical offshore wind farm for Jacksonville, Florida. M.Sc. thesis, University of Florida (2007)

7. Yang, Q., Chen, G.Q., Liao, S., Zhao, Y.H., Peng, H.W., Chen, H.P.: Environmental Sustainability of Wind Power: An Emergy Analysis of a Chinese Wind Farm. Ren. Sus. Ener. Rev. 25, 229-239 (2013) 
8. Costa, M., Agostinho, F.: Net Emergy Assessment Of Wind-Electricity Generation In The Brazilian Northeast Region. In: Brown, M.T. et al. (eds.), Proceedings of the 9th Biennial Emergy Conference, University of Florida, Gainesville (2016)

9. Slesser, M. (ed.): Energy analysis Workshop on methodology and Conventions. Stockholm, Sweden, IFIAS 89pp. (1974)

10. Sheehan, J., Camobreco, V., Duffield, J., Graboski, M., Shapouri, H.: Life Cycle Inventory Of Biodiesel And Petroleum Diesel For Use In An Urban Bus. Final Report, National Renewable Energy Laboratory, USA (1998)

11. Jensen, A.A., Hoffman, L., Moller, B.T., Schmidt, A., Christiansen, K., Elkington, J., van Dijk, F. (eds): Life Cycle Assessment: A Guide to Approaches, Experiences and Information Sources. European Environmental Agency (1997)

12. Brown, M.T., Ulgiati, S.: Emergy Analysis and Environmental Accounting. Enc. Ener. 2, 329-353 (2004)

13. Lenzen, M., Munksgaard, J.: Energy and CO2 life-cycle Analysis of Wind Turbines - Review and Applications. Ren. Ener. 26, 339-362 (2002)

14. Riposo, D.: Integrated Energy And Environmental Analysis Of Utility-Scale Wind Power Production. M.Sc. thesis, University of Maryland (2008)

\section{Appendix}

Appendix A. Intensity factors used in this work.

\begin{tabular}{|c|c|c|c|c|}
\hline \multirow[b]{2}{*}{ Item } & \multirow[b]{2}{*}{ Unit } & \multicolumn{2}{|c|}{ Intensity factors ${ }^{a}$} & \multirow[b]{2}{*}{ Observation } \\
\hline & & $\begin{array}{l}\mathrm{MJ}_{\text {eq. }} / \\
\text { Unit }\end{array}$ & $\begin{array}{l}\mathrm{kgCO}_{2 \text { eq. }} / \\
\text { Unit }\end{array}$ & \\
\hline Wind & $\mathrm{b}$ & $\mathrm{b}$ & $\mathrm{b}$ & $\mathrm{b}$ \\
\hline Steel & $\mathrm{kg}$ & $4.05 \mathrm{E}+00$ & $3.44 \mathrm{E}-01$ & Market for hot rolling, steel, GLO \\
\hline Fiber glass & $\mathrm{kg}$ & $3.67 \mathrm{E}+01$ & $3.12 \mathrm{E}+00$ & Market for glass fibre, GLO \\
\hline Epoxy & $\mathrm{kg}$ & $1.22 \mathrm{E}+02$ & $8.33 \mathrm{E}+00$ & Market for epoxy resin, liquid, GLO \\
\hline Copper & $\mathrm{kg}$ & $4.45 \mathrm{E}+01$ & $4.61 \mathrm{E}+00$ & Market for copper, GLO \\
\hline Aluminum & $\mathrm{kg}$ & $8.82 \mathrm{E}+00$ & $8.42 \mathrm{E}-01$ & Market for sheet rolling, aluminum, GLO \\
\hline Glass & $\mathrm{kg}$ & $1.21 \mathrm{E}+01$ & $1.11 \mathrm{E}+00$ & Market for flat glass, uncoated, GLO \\
\hline Polyester & $\mathrm{kg}$ & $9.43 \mathrm{E}+01$ & $7.19 \mathrm{E}+00$ & $\begin{array}{l}\text { Market for polyester resin, unsaturated, } \\
\text { GLO }\end{array}$ \\
\hline Diesel & $\mathrm{J}$ & $1.43 \mathrm{E}-06$ & $9.81 \mathrm{E}-08$ & Diesel, burned in building machine, GLO \\
\hline Concrete & $\mathrm{kg}$ & $6.47 \mathrm{E}-01$ & $1.05 \mathrm{E}-01$ & $\begin{array}{l}\text { Market for concrete, } 50 \mathrm{MPa} \text {, GLO (density } \\
\text { of } 3800 \mathrm{~kg} / \mathrm{m}^{3} \text { ) }\end{array}$ \\
\hline Water & $\mathrm{b}$ & $\mathrm{b}$ & $\mathrm{b}$ & b \\
\hline Electricity & $\mathrm{kWh}$ & $5.79 \mathrm{E}-02$ & $2.53 \mathrm{E}-01$ & $\begin{array}{l}\text { Electricity production, hydro, reservoir, } \\
\text { tropical region, BR }\end{array}$ \\
\hline Gasoline & $\mathrm{kg}$ & $5.53 \mathrm{E}+01$ & $6.48 \mathrm{E}-01$ & $\begin{array}{l}\text { Market for light fuel oil, } \mathrm{CH} \text { (HHV of } 45 \\
\mathrm{MJ} / \mathrm{kg} \text { ) }\end{array}$ \\
\hline L\&S & b & $\mathrm{b}$ & $\mathrm{b}$ & b \\
\hline
\end{tabular}

a All intensity factors were obtained from Ecoinvent Database v.3.1-2014 (www.ecoinvent.ch);

${ }^{\mathrm{b}}$ Wind, Water and L\&S (Labor \& Services) are not accounted for both methodologies considered in this work (energy analysis and emission inventory). 
Appendix B. Emission factors (in $\mathrm{kg} / \mathrm{MJ}$ ) affecting global warming potential from diesel oil combustion in an industrial boiler.

\begin{tabular}{ccccc}
\hline $\mathrm{CO}_{2}$ & $\mathrm{CH}_{4}$ & $\mathrm{~N}_{2} \mathrm{O}$ & $\mathrm{CO}$ & Hydrocarbons \\
\hline 0.0762 & $8.3 \mathrm{E}-8$ & $3.7 \mathrm{E}-7$ & 0.017 & $6.7 \mathrm{E}-7$ \\
\hline Source: Sheehan et al. [10]
\end{tabular}

Source: Sheehan et al. [10] 